\title{
Modification of Cellulose with ZnO Nanoparticles: From Sugarcane Bagasse to Antimicrobial Composite
}

\author{
Jyoti Laxmi Sharma ${ }^{1}$, Rakesh Kumar Sharma ${ }^{1}$, Meena Kumari², \\ Banwari Lal Choudhary ${ }^{3}$, Veena Dhayal ${ }^{4, *}$ \\ 1 Department of Biosciences, Manipal University Jaipur, Jaipur, Rajasthan 303007, India \\ 2 Department of Civil Engineering, Manipal University Jaipur, Jaipur, Rajasthan 303007, India \\ ${ }^{3}$ Department of Physics, Banasthali Vidhyapith, Rajasthan 304022, India \\ ${ }^{4}$ Department of Chemistry, Manipal University Jaipur, Jaipur, Rajasthan 303007, India
}

(Received 16 July 2021; revised manuscript received 20 October 2021; published online 25 October 2021)

\begin{abstract}
Cellulose fibers were extracted from sugarcane bagasse and then modified with $\mathrm{ZnO}$ nanoparticles $(\mathrm{NPs})$ by a sol-gel process using an oxime modified $\mathrm{Zn}$ precursor $\left[\mathrm{ZnCl}_{2} .2\left\{\mathrm{HONC}\left(\mathrm{CH}_{3}\right)_{2}\right\}\right]$ in different gram ratios to make them antimicrobial. $\mathrm{ZnO}$ modified cellulose fibers were further characterized by Fourier transform infrared (FTIR), X-ray diffraction (XRD), scanning electron microscopy (SEM) studies. Obtained results confirmed well-dispersed hexagonal wurtzite $\mathrm{ZnO}$ NPs onto the surface of cellulose. Lower band gaps (2.87-2.48 eV) were observed in $\mathrm{ZnO}$ modified cellulose as compared to pure $\mathrm{ZnO}$ NPs $(\sim 3.3 \mathrm{eV})$. Antibacterial activities were examined against Staphylococcus aureus and Escherichia coli in different ratios (1:1, 1:2 and 1:3) and concentrations (1.5 to $\left.200 \mathrm{mg} \cdot \mathrm{ml}^{-1}\right)$ of $\mathrm{ZnO}$ modified cellulose. The antifungal activity of $\mathrm{ZnO}$ modified cellulose (1:1) was evaluated against Aspergillus niger, Phanerochaete chrysosporium, and Geotrichum candidum. $\mathrm{ZnO}$ modified cellulose ratio of 1:1 at the tested concentration remarkably inhibited the mycelial growth of the fungus. The antifungal efficacy of $\mathrm{ZnO}$ modified cellulose depended on the concentration of the sample concerned, therefore maximal inhibition of mycelia growth occurred at the highest concentration $(5 \mathrm{mg})$.
\end{abstract}

Keywords: Zinc oxide nanoparticles, Zinc oxide modified cellulose, Staphylococcus aureus, Escherichia coli, Aspergillus niger, Phanerochaete chrysosporium, Geotrichum candidum.

DOI: 10.21272/jnep.13(5).05028

PACS numbers: 61.46. + w, 61.46.Df, 61.82.Rx

\section{INTRODUCTION}

Fabrics that are presently being used in healthcare (such as PPE kits during current COVID-19) act as a barrier to protect the wearer from infectious microorganisms [1]. However, these fabrics, usually, do not have the ability to avoid the spread of microbes, as the surface of the material allows adherence and growth of microorganisms with time [2]. This leads to further spread of microbes due to careless handling of healthcare fabrics and improper disposal practices. Strategically incorporated into fabrics metal-based nanoparticles (NPs), such as copper [3], silver [4], zirconia [5], titania [6] and other active organic ingredients [4], can act as antimicrobial agents. This confirms limited penetration and growth of microbial contaminants on healthcare fabrics. Thus, fabrics coated with metal NPs have the potential to reduce the risk of secondary infections by regulating microbial communication [7]. Nowadays, the design of antimicrobial fabrics requires to be followed by some important aspects, such as the use of cheap raw materials, biocompatible and biodegradable properties of the designed fabrics [8].

Cellulose, one of the excellent and low-cost abundant biopolymers, can be easily extracted from agricultural waste material and has received a lot of attention in proton-conducting membranes water treatment, transparent displays, supercapacitors, wound dressings, super absorbents, tissue engineering, food packaging, etc. [9]. But cellulose does not show any antimicrobial activity due to its neutral properties; however, considerable efforts have been made to modify cellulose with different organic and inorganic NPs, such as $\mathrm{ZnO}$, $\mathrm{TiO}_{2}, \mathrm{CuO}$, and $\mathrm{Ag}$ to incorporate antimicrobial properties [10]. $\mathrm{ZnO}$ is a wide band gap $\left(E_{g}=3.37 \mathrm{eV}\right)$ semiconductor metal oxide with potential application in catalytic, electrical, photochemical and optical fields [11]. It assumes a significant role in the formation of reactive oxygen species (ROS) that lead to the antimicrobial role of $\mathrm{ZnO} \mathrm{NPs}$ by damaging the protective layer and plasma membranes of microbes, such as $E$. coli and $S$. aureus [12]. $\mathrm{ZnO}$ has gained much attention in food engineering applications also because of its low toxicity to the human body [13].

Modification of cellulose fibers with $\mathrm{ZnO}$ has been done (i) using a hydrothermal process to deposit $\mathrm{ZnO}$ NPs on the cellulose surface using $\mathrm{ZnO}$ precursor [14], (ii) by immersing cellulose fibers in an aqueous dispersion of $\mathrm{ZnO}$ NPs [15] or (iii) by sol-gel deposition of $\mathrm{ZnO}$ $\mathrm{NPs}$ on the cellulose surface using $\mathrm{ZnO}$ precursor [16]. $\mathrm{ZnO}$ precursors used were $\mathrm{Zn}$ (II) acetate or $\mathrm{Zn}$ (II) nitrate [17]. We have recently designed an oxime modified precursor, $\left[\mathrm{ZnCl}_{2} .2\left\{\mathrm{HONC}\left(\mathrm{CH}_{3}\right)_{2}\right\}\right.$ ], and used it for $\mathrm{ZnO}$ NPs preparation in our earlier report [18]. We have used the same precursor in the current study to modify cellulose fibers with $\mathrm{ZnO}$ NPs.

The antibacterial properties of $\mathrm{ZnO}$ modified cellulose fibers are well documented by some researchers, but their antifungal properties are still unexplored [18].

Therefore, the novelty of the current research is to examine the antifungal properties of $\mathrm{ZnO}$ modified

\footnotetext{
*dhayal21v@gmail.com
} 
cellulose against Phanerochaete chrysosporium (wood degrading fungus) along with Aspergillus niger and Geotrichum candidum as well as to examine the antibacterial properties against Staphylococcus aureus and Escherichia coli.

\section{EXPERIMENTAL}

Substances and equipment were dried and purified using traditional methods [19]. Acetoxime and $\left[\mathrm{ZnCl}_{2} .2\left\{\mathrm{HONC}\left(\mathrm{CH}_{3}\right)_{2}\right\}\right]$ were synthesized as reported earlier [18]. Cellulose fibers were extracted from sugarcane bagasse (SB) as per the reported method [20].

FTIR spectra (4000-500 $\left.\mathrm{cm}^{-1}\right)$ were observed on a Bruker ALPHA Fourier transform infrared spectrometer. Thermo-gravimetric (TG) analyses were conducted on Shimadzu DTG-60H at a heating rate of $20^{\circ} \mathrm{C} \cdot \mathrm{min}^{-1}$ from 30 to $600{ }^{\circ} \mathrm{C}$ in flowing air environment. The crystalline cellulose composition and $\mathrm{ZnO}$ modified cellulose were evaluated using a Bruker D8 advance Diffractometer with a $\mathrm{Cu}-\mathrm{K} a$ source at $\lambda=1.544 \AA$ in $2 \theta$ range of $10^{\circ}$ to $70^{\circ}$. The surface morphology and elemental compositions of the formed composites and cellulose were investigated using SEM coupled with EDX on Nova Nano FE-SEM 450 (FEI). A Shimadzu UV-2600 spectrophotometer was used to assess the UV-visible absorbance of the formed samples. Cellulose fibers were extracted from SB by a physicochemical method [20].

A zinc oxide hydrogel was prepared using

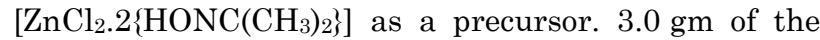
precursor was dissolved in ethanol $(\sim 30 \mathrm{ml})$ and $0.5 \mathrm{ml}$ of ammonia solution was added dropwise with stirring. This mixture was further stirred for $2 \mathrm{~h}$. To ensure complete hydrolysis, some more ammonia solution $(0.5 \mathrm{ml})$ was added to the mixture, then stirred overnight. The obtained white precipitate was thoroughly washed with ethanol and distilled water. The obtained solid was dried in an oven to get hydrogel of $\mathrm{ZnO}$. $\mathrm{ZnO}$ modified cellulose was prepared using $\mathrm{ZnO}$ hydrogel and cellulose fibers in gram ratios of 1:1 (A), 1:2 (B), and $1: 3(\mathbf{C})$. About $1.0 \mathrm{~g}$ of cellulose fibers and $1.0 \mathrm{~g}$ of $\mathrm{ZnO}$ hydrogel were separately suspended in $50 \mathrm{ml}$ of distilled water and stirred for $24 \mathrm{~h}$. The obtained $\mathrm{ZnO}$ sol was further mixed with a suspension of cellulose fibers and placed on stirring for 4 more days. The resultant mixture was dried in a hot oven $\left(\sim 100^{\circ} \mathrm{C}\right)$ and further sintered at $150{ }^{\circ} \mathrm{C}$ for $1 \mathrm{~h}$ to yield (A).

Samples (B) and (C) were also synthesized by a similar method taking 1:2 and 1:3 ratios of $\mathrm{ZnO}$ hydrogel and cellulose fibers, respectively.

The antibacterial properties of $\mathrm{ZnO}$ modified cellulose were tested against Escherichia coli and Staphylococcus aureus, which were obtained only from Microbial Type Culture Collection, IMTECH, Chandigarh, India. Agar well diffusion method was used to evaluate the antibacterial effects of $\mathrm{ZnO}$ modified cellulose. Steadily growing bacterial inoculums in nutrient broth medium $(100 \mu \mathrm{l}$ of $1 \mathrm{OD})$ were spread on the agar plates using a sterilized glass spreader. Wells with a diameter of $7 \mathrm{~mm}$ were prepared in inoculated agar plates using a stainless steel borer under sterile conditions and loaded with $100 \mu \mathrm{l}$ of suspension with different concentrations (1.5 to $200 \mathrm{mg} \cdot \mathrm{ml}^{-1}$ ) of $\mathrm{ZnO}$ modified cellulose. Plates were incubated at $37^{\circ} \mathrm{C}$ for $24 \mathrm{~h}$ along with a suitable control, and the diameter of the inhibition zone was observed. The experiment was repeated 3 times for each bacterium under the same conditions, and the average values for the standard deviation were presented.

The antifungal activity of $\mathrm{ZnO}$ modified cellulose was tested against $A$. niger, $P$. chrysosporium and $G$. candidum. Varying concentrations of $\mathrm{ZnO}$ modified cellulose (1:1), $20 \mathrm{ml}$ of potato dextrose agar (PDA) were added and aseptically poured into a pre-sterilized Petri dish $(90 \times 15 \mathrm{~mm})$. The control plate consisted of PDA media only. All Petri dishes were inoculated with one agar disc in the center of the plate containing a 7day old fungal culture. Sterilized plates were incubated at $28{ }^{\circ} \mathrm{C}$ for 7 to 12 days and the experiment was repeated 3 times. The mycelial growth was measured, and the radial inhibition rate was calculated.

\section{RESULTS AND DISCUSSION}

Cellulose fibers were extracted from SB by physicochemical method [20].

The extracted cellulose fibers were characterized and further modified with $\mathrm{ZnO}$ NPs using $\left[\mathrm{ZnCl}_{2} .2\left\{\mathrm{HONC}\left(\mathrm{CH}_{3}\right)_{2}\right\}\right]$ as a precursor. The modification of the $\mathrm{ZnO}$ sol with cellulose was carried out in a gram ratio of $1: 1,1: 2$ and $1: 3$ to obtain composites (A), (B) and (C), respectively.

The range of pure cellulose revealed all the peaks corresponding to different functional groups (Fig. 1) [12]. The FTIR spectra of $\mathrm{ZnO}$ modified cellulose showed all characteristic peaks of cellulose along with an extra peak at $524-530 \mathrm{~cm}^{-1}$ which could be assigned to $\mathrm{ZnO} \mathrm{NPs}$. In addition, in $\mathrm{ZnO}$ modified composite, a strong peak was observed at $1062 \mathrm{~cm}^{-1}$, and the peak at $3342 \mathrm{~cm}^{-1}$ shifted to slightly higher wavenumbers could be due to the interaction of $\mathrm{ZnO} N \mathrm{NP}$ and $\mathrm{OH}$ group of cellulose fibers.

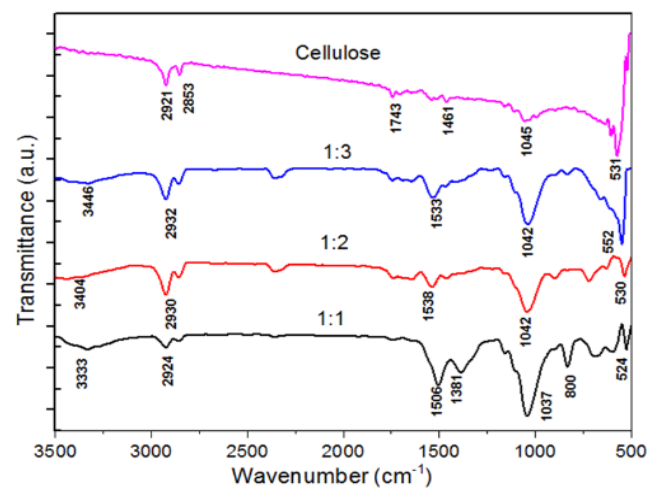

Fig. 1 - FTIR spectra of $\mathrm{ZnO}$ modified cellulose (1:1, 1:2 and 1:3) and cellulose

The XRD profile of cellulose displayed typical diffraction peaks at $2 \theta=16.14^{\circ}, 22.64^{\circ}$, and $32.84^{\circ}$ (Fig. 2) [12]. Peaks at $2 \theta=31.76^{\circ}, 34.54^{\circ}, 36.39^{\circ}, 47.52^{\circ}, 56.48^{\circ}$, $62.82^{\circ}, 66.37^{\circ}, 67.92^{\circ}, 69.00^{\circ}, 72.40^{\circ}$, and $76.88^{\circ}$ correspond to diffraction from planes (100), (002), (101), (102), (110), (103), (200), (112), (201), (004), (202), representing the presence of a hexagonal wurtzite phase of zinc oxide (JCPDS: 00-036-1451) [18]. The intensity of cellulose crystalline peaks gradually increased with an increase in cellulose concentration. 


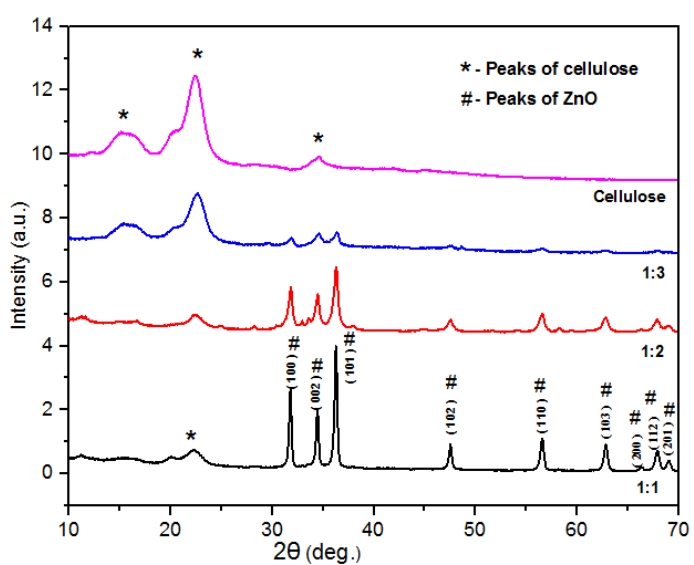

Fig. 2 - XRD spectra ZnO modified cellulose (1:1, 1:2 and 1:3) and cellulose

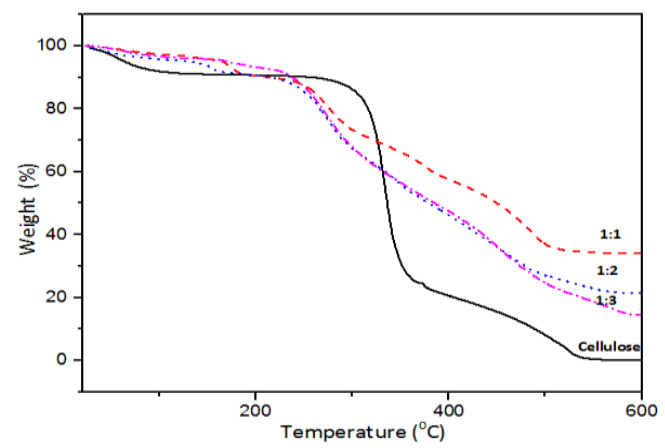

Fig. 3 - TGA curve of $\mathrm{ZnO}$ modified cellulose (1:1, 1:2 and 1:3) and cellulose

Minor weight losses were noticed in all samples below $100{ }^{\circ} \mathrm{C}$, which were due to the evaporation of $\mathrm{ab}$ sorbed water from the samples (Fig. 3).

The difference in the onset of thermal degradation of pure cellulose and $\mathrm{ZnO}$ modified cellulose could be resulted from the catalytic activity of $\mathrm{ZnO} \mathrm{NPs}$, which assisted faster disintegration of the cross-linking in the carbon skeleton. But at higher temperatures, $\mathrm{ZnO}$ modified cellulose revealed better thermal stability compared to pure cellulose. It is assumed that the addition of $\mathrm{ZnO} N \mathrm{NP}$ to cellulose chains improved the thermal stability of composites due to strong interactions between cellulose and $\mathrm{ZnO}$ NPs. At the end of heating, the total weight loss of cellulose was $99.8 \%$, whereas the total weight loss of $\mathrm{ZnO}$ modified cellulose was 67.1, 79.8 and $86.2 \%$ for 1:1 (A), $1: 2$ (B) and 1:3 (C), respectively.

In order to demonstrate a homogeneous distribution of the inorganic phase on the cellulose substrate surface, a SEM analysis was recorded (Fig. 4). As it can be observed in all composites, Zn concentration does not show significant gradients from one area to another, thus confirming a uniform distribution of $\mathrm{ZnO}$ NPs on the cellulose surface (Fig. 4).

$\mathrm{ZnO}$ modified cellulose in a ratio of $1: 1,1: 2$, and $1: 3$ inhibited the growth of both bacteria $(S$. aureus and $E$. coli), while cellulose as a control did not exhibit any inhibition zone. The growth of $S$. aureus was inhibited by all ratios of $\mathrm{ZnO}$ modified cellulose as compared to E. coli. Earlier studies also demonstrated that cellulose did not show any inhibition of bacterial growth, but $\mathrm{ZnO}$ modified cellulose exhibited antimicrobial activity against $S$. aureus and $E$. coli [12]. In this study, the minimum inhibitory concentration (MIC) of $\mathrm{ZnO}$ modified cellulose was $25 \mathrm{mg} \cdot \mathrm{ml}^{-1}$ in a ratio of $1: 1$ and $50 \mathrm{mg} \cdot \mathrm{ml}^{-1}$ in a ratio of $1: 2$ for $E$. coli (Fig. 5), while it was $1.5 \mathrm{mg} \cdot \mathrm{ml}^{-1}$ in a ratio of $1: 1$ and $3 \mathrm{mg} \cdot \mathrm{ml}^{-1}$ in a ratio of $1: 2$ and 1:3 for $S$. aureus (Fig. 6).

The results indicated that antimicrobial activity was observed because of the presence of $\mathrm{ZnO}$ nanoparticles in samples. Higher concentration of the cellulose in $\mathrm{ZnO}$ modified cellulose resulted into reduced inhibition zone due to relatively lower concentration of $\mathrm{ZnO}$ nanoparticles than cellulose. In earlier literature, we have reported that $\mathrm{ZnO}$ nanoparticles demonstrated better antibacterial activity against $S$. aureus than $E$. coli, even at the lowest concentration of $0.05 \mathrm{mg} \mathrm{ml}^{-1}$ [18].

The antibacterial performances of the samples were dependent on the concentration [18]. E. coli was more tolerant towards $\mathrm{ZnO}$ NPs than S. aureus, as demonstrated by higher inhibition zone [18]. This may be due to the presence of an outer membrane present in Gramnegative bacteria, which plays a role of an enterable obstacle to the penetration of ROS. Similar antibacterial activity of NPs against $S$. aureus and $E$. coli was also observed earlier [12].
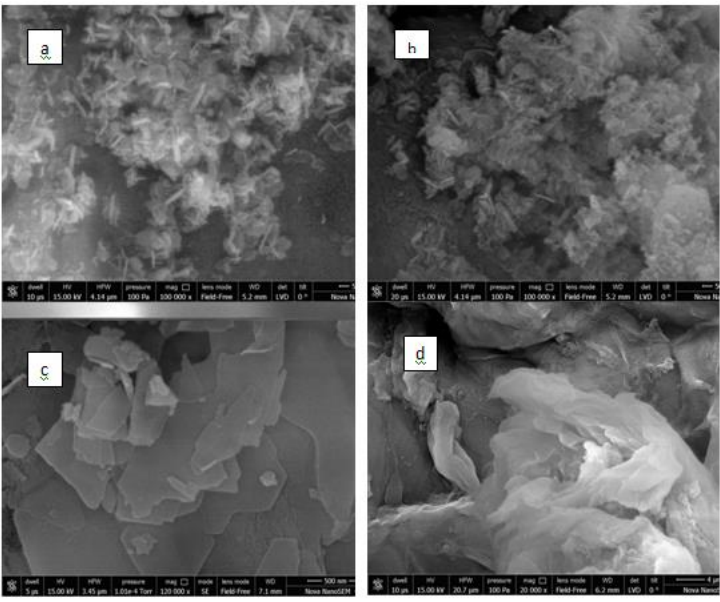

Fig. 4 - SEM micrographs of $\mathrm{ZnO}$ modified cellulose: (a) 1:1, (b) 1:2, (c) 1:3, and (d) cellulose

$\mathrm{ZnO}$ modified cellulose in a ratio of 1:1 showed radial inhibition in all fungi (A. niger, $P$. chrysosporium and $G$. candidum). A. niger and $G$. candidum did not show any response for $1: 2$ and 1:3 ratios. A. niger did not respond to any variations in concentration (1 to $2 \mathrm{mg}$ ), but $P$. chrysosporium, a wood degrading fungus, was highly sensitive to all concentrations. It showed excellent results at a concentration of $5 \mathrm{mg}$. G. candidum showed better results at different concentrations ( 1 to $5 \mathrm{mg}$ ) compared to $A$. niger. G. candidum exhibited a response against all concentrations of $\mathrm{ZnO}$ modified cellulose in a ratio of $1: 1$, being the best at a concentration of $5 \mathrm{mg}$ (Fig. 8, Fig. 9). 


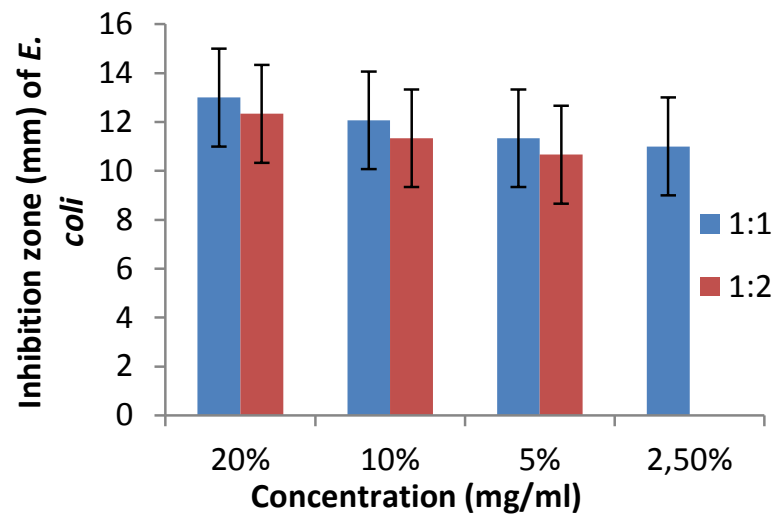

Fig. 5 - Zone of inhibition $(\mathrm{mm})$ of $E$. coli against $\mathrm{ZnO}$ modified cellulose (1:1 and 1:2)

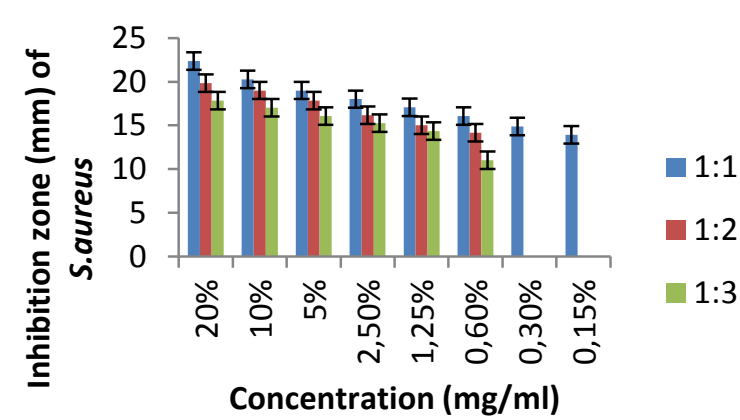

Fig. 6-Zone of inhibition $(\mathrm{mm})$ of $S$. aureus against $\mathrm{ZnO}$ modified cellulose (1:1, 1:2 and 1:3)

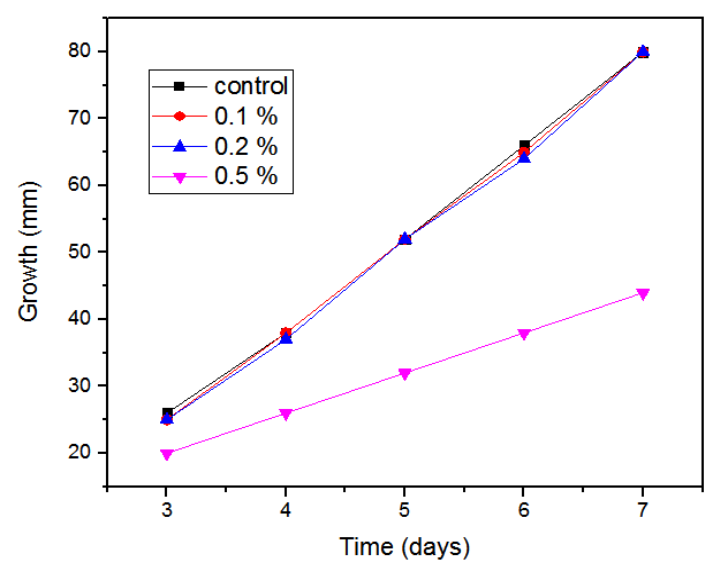

Fig. 7 - The effect of $\mathrm{ZnO}$ modified cellulose (1:1) on the growth of $A$. niger

\section{REFERENCES}

1. States PAU HHS Public Access 10, 180 (2016).

2. N. Patojenlerin, D. Kumaş, T. Üzerindeki, Y. Süreleri, Persistence of Nosocomial Pathogens on Various Fabrics, 28 (2012)

3. Q. Xu, X. Ke, N. Ge, L. Shen, Y. Zhang, F. Fu, X. Liu, Fibers Polymer 19, 1004 (2018).

4. Y. Xu, S. Li, X. Yue, W. Lu, BioRes. 13, 2150 (2018)

5. J.F. Kennedy, S.A. Barker, A. Zamir, Antimicrob Agents

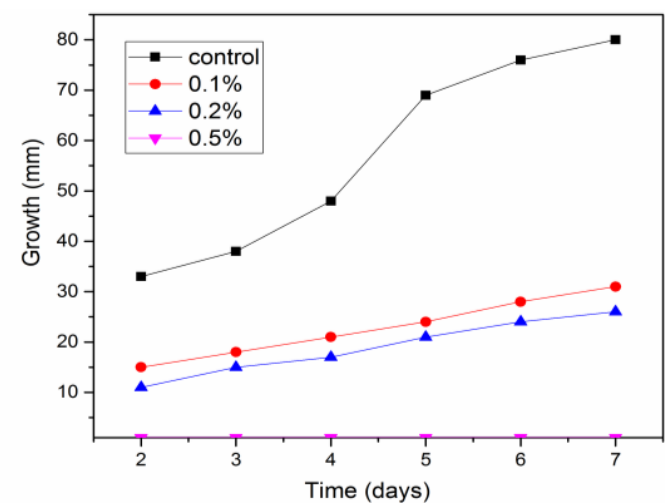

Fig. 8-The effect of $\mathrm{ZnO}$ modified cellulose (1:1) on the growth of $P$. chrysosporium

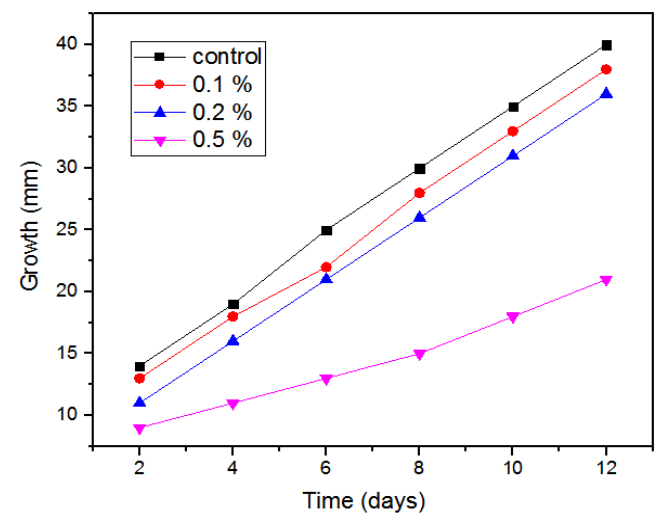

Fig. 9- The effect of $\mathrm{ZnO}$ modified cellulose (1:1) on the growth of G. candidum

\section{CONCLUSIONS}

Cellulose fibers were successfully extracted from sugarcane bagasse, characterized and modified with $\mathrm{ZnO} \mathrm{NPs}$ in different ratios using the sol-gel method. $\mathrm{ZnO}$ NPs were homogenously dispersed over the cellulose surface in the form of hexagonal wurtzite structure. The immobilization of $\mathrm{ZnO}$ NPs improved the antimicrobial efficacy of $\mathrm{ZnO}$ as indicated by antibacterial and antifungal studies. $\mathrm{ZnO}$ modified cellulose was found to be a potent antimicrobial agent against $E$. coli, $S$. aureus, A. niger, P. chrysosporium and G. candidum.

\section{ACKNOWLEDGEMENTS}

The authors are grateful to MNIT, Jaipur, for SEM studies and CAF, Manipal University, Jaipur, for TGA analysis. VD is thankful to Manipal University, Jaipur, for financial support (grant no. EF/2017-18/QE04-02).

Chemother 6, 777 (1974).

6. Q. Li, S. Mahendra, D.Y. Lyon, L. Brunet, M.V. Liga, D. Li, P.J.J. Alvarez, Water Res. 42, 4591 (2008).

7. M. Gouda, A. Aljaafari, Y. Al-Fayz, W.E. Boraie, J. Nanomater., 586904 (2015)

8. M. Daria, L. Krzysztof, M. Jakub, J. Clean. Prod., 268 (2020).

9. Nanocomposites: new trends and developments 
(F. Ebrahimi Ed.) (BoD - Books on Demand: 2012).

10. A. Farooq, M.K. Patoary, M. Zhang, H. Mussana, M. Li, M.A. Naeem, M. Mushtaq, A. Farooq, L. Liu, Int. J. Biol. Macromol. 154, 1050 (2020).

11. Us Varma, P. Gautham, Dr. Kumar, Km. Sreekanth, G. Sivasubramanian, Km. Sreedhar, Rasāyan J. Chem. 11 No 4, 1491 (2018).

12. K. Lefatshe, C.M. Muiva, L.P. Kebaabetswe, Carbohydr. Polym. 164, 301 (2017).

13. N. Martins, C. Freire, C. Neto, A.J.D. Silvestre, J. Causio, G. Baldi, P. Sadocco, T. Trindade, Colloid. Surf. A: Physicochemical. Eng. Asp. 417, 111 (2013).

14. D. Shao, Y. Gao, K. Cao, Q. Wei, J. Text. Inst. 108, 1391 (2017).
15. L. M. Pintarić, M.S. Škoc, V.L. Bilić, I. Pokrovac, I. Kosalec, I. Rezić, Polymers (Basel) 12, 1210 (2020).

16. A. Kathalingam, H.-C. Park, S.-D. Kim, Hyun-Seok Kim, S. Velumani, T. Mahalingam, J. Mater. Sci. Mater. Electron. 26, 5724 (2015)

17. E. Bacaksız, M. Parlak, M. Tomakin, A. Özçelik, M. Karakız, M. Altunba, J. Alloys Compd. 466,447 (2008).

18. A. Saini, J. Sharma, R. Sharma, A. Chaudhary, D. Sharma, V. Dhayal, J. Sol-Gel Sci. Technol. 644 (2019).

19. Armarego, L.F. Wilfred, C.L.L. Chai, Purification of Laboratory Chemicals (Elsevier: 2009).

20. Morais E. De, T. Jessika, K. Bruna, Ind. Crop. Prod. 33, 63 (2010).

\title{
Модифікація целюлози наночастинками $\mathrm{ZnO}$ від жому цукрової тростини до антимікробного композиту
}

\author{
Jyoti Laxmi Sharma ${ }^{1}$, Rakesh Kumar Sharma ${ }^{1}$, Meena Kumari ${ }^{2}$, \\ Banwari Lal Choudhary ${ }^{3}$, Veena Dhayal ${ }^{4}$
}

\author{
${ }^{1}$ Department of Biosciences, Manipal University Jaipur, Jaipur, Rajasthan 303007, India \\ 2 Department of Civil Engineering, Manipal University Jaipur, Jaipur, Rajasthan 303007, India \\ ${ }^{3}$ Department of Physics, Banasthali Vidhyapith, Rajasthan 304022, India \\ ${ }^{4}$ Department of Chemistry, Manipal University Jaipur, Jaipur, Rajasthan 303007, India
}

\begin{abstract}
Волокна целюлози були вилучені з жому цукрової тростини і потім модифіковані наночастинками (HЧ) $\mathrm{ZnO}$ за допомогою золь-гель процесу з використанням оксим-модифікованого прекурсора $\mathrm{Zn}$ $\left[\mathrm{ZnCl}_{2} .2\left\{\mathrm{HONC}\left(\mathrm{CH}_{3}\right)_{2}\right\}\right]$ у різних вагових співвідношеннях, щоб зробити їх антимікробними. Модифіковані $\mathrm{ZnO}$ волокна целюлози додатково характеризувались інфрачервоною спектроскопіею з перетворенням Фур'є (FTIR), рентгенівською дифракцією (XRD) та скануючою електронною мікроскопією (SEM). Отримані результати підтвердили наявність добре диспергованих НЧ гексагонального вюрцита $\mathrm{ZnO}$ на поверхні целюлози. Більш низькі значення ширини забороненої зони $(2,87-2,48$ еВ) спостерігалися в модифікованій $\mathrm{ZnO}$ целюлозі в порівнянні з чистими $\mathrm{HЧ} \mathrm{ZnO}$ ( 3,3 еВ). Антибактеріальну активність досліджували щодо Staphylococcus aureus i Escherichia coli при різних співвідношеннях (1:1, $1: 2$ і 1:3) і концентраціях (1,5-200 мг·мл $\left.{ }^{-1}\right)$ модифікованої $\mathrm{ZnO}$ целюлози. Протигрибкову активність модифікованої $\mathrm{ZnO}$ целюлози (1:1) оцінювали щодо Aspergillus niger, Phanerochaete chrysosporium i Geotrichum candidum. Співвідношення 1:1 модифікованої ZnO целюлози при випробуваній концентрації помітно інгібувало ріст міцелію гриба. Протигрибкова ефективність модифікованої $\mathrm{ZnO}$ целюлози залежала від концентрації досліджуваного зразка, тому максимальне інгібування росту міцелію відбувалося при найвищій концентрації (5 мг).
\end{abstract}

Ключові слова: Наночастинки оксиду цинку, Модифікована оксидом цинку целюлоза, Staphylococcus aureus, Escherichia coli, Aspergillus niger, Phanerochaete chrysosporium, Geotrichum candidum. 